\title{
Cidade e literatura: um encontro com Raskólnikov nas ruas de São Petersburgo
}

\author{
Heloísa Alves Braga*
}

\begin{abstract}
Resumo
Sabendo que a cidade é um lugar de encontros e desencontros, vários autores da literatura universal a utilizaram como estratégia narrativa capaz de "unir" ficção e realidade em um ambiente de constantes mudanças e transformações. Dostoiévski seguiu também por estas veredas e nos mostrou seus personagens em meio a seus conflitos vividos nos grandes centros do Império Russo. Para evidenciar a importância da cidade como estratégia narrativa nas obras do famoso escritor russo, foi analisada a obra Crime e Castigo, história que se passa em São Petersburgo do século XIX, cidade na qual o protagonista, Raskólnikov, vai aprofundando em suas teorias e se "afundando" em seus pensamentos e culpas. O movimento regular da cidade bem como o vagar de Raskólnikov pelas ruas misturam-se, em uma narrativa que evidencia tanto o dilema do protagonista quanto a diversidade de pessoas que caminham por São Petersburgo, cada uma com seus dilemas e pensamentos e desconstruções e reconstruções/destruições, modificações que são refletidas nas mudanças diárias da cidade. Dessa forma, este artigo busca evidenciar a tênue linha entre ficção e realidade tão bem trabalhada por Dostoiévski.
\end{abstract}

Palavras-chave: Cidade. Dostoiévski. Conflitos e mudanças. Ficção e realidade.

\section{Scènes Cariocas: la théâtralité des espaces dans trois nouvelles de Machado de Assis}

\begin{abstract}
Resumen
Sabiendo que la ciudad es un lugar de encuentros y desencuentros, varios autores de la literatura universal la utilizaron como estrategia narrativa capaz de "unir" ficción y realidad en un ambiente de constantes cambios y transformaciones. Dostoiévski siguió también por estas veredas y nos mostró sus personajes en medio de sus conflictos vividos en los grandes centros del Imperio Ruso. Para evidenciar la importancia de la ciudad como estrategia narrativa en las obras del famoso escritor ruso, se analizó la obra Crimen y Castigo, historia que se desarrolla en San Petersburgo del siglo XIX, ciudad en la que el protagonista, Raskólnikov, va profundizando en sus teorías y, "Hundiéndose" en sus pensamientos y culpas. El movimiento regular de la ciudad, así como el vagar de Raskólnikov por las calles se mezclan, en una narrativa que evidencia tanto el dilema del protagonista como la diversidad de personas que caminan por San Petersburgo, cada una con sus dilemas y pensamientos y desconstrucciones y reconstrucciones / destrucciones, modificaciones que se reflejan en los cambios diarios de la ciudad. De esta forma, este artículo busca evidenciar la tenue línea entre ficción y realidad tan bien trabajada por Dostoiévski.
\end{abstract}

Palabras-clave: Ciudad. Dostoiévski. Conflictos y cambios. Ficción y realidad.

Recebido: 28/03/2018

Aceito: 05/10/2018

\footnotetext{
* Secretaria de Educação de Minas Gerais. Professora de Língua Portuguesa. Mestra em Letras pela Pontifícia Universidade Católica de Minas Gerais. (PUC Minas).
} 


\section{Introdução}

A cidade é um lugar de transformações, que revela as modificações das pessoas que nela habitam, transformações essas que encontram eco nas mudanças ocorridas em sua própria estrutura, nas evoluções dos prédios, da arquitetura. Como afirma Oliveira, "[a] cidade é, pois, dinâmica, evolui, cresce modifica-se, transformando-se num local mais ou menos aprazível, dependendo de toda a sua trajetória, dependendo de quem a vê, ou ainda de quem a vive ou a estuda" (OLIVEIRA, 2009, p.8).

Este foi um dos motivos que levou diversos escritores da literatura universal a utilizar a cidade como estratégia narrativa para desenvolver seus romances. Conforme Brum, "A narrativa torna-se necessária e nasce como decorrência da anterioridade da imaginação e da sua posterior realização na representação sobre a concretude física." (BRUM, 2009, p.22).

As cidades foram colocadas em evidência por diversos autores que revelaram a influência do ambiente urbano na construção das personagens. Eles misturaram elementos do cotidiano das cidades, suas histórias, suas mudanças e os moradores reais, que viveram histórias reais, com personagens e histórias ficcionais. Américo afirma "A ideia é traduzir um setor da realidade em linguagem, transformá-lo em texto, isto é, em uma informação codificada, e introduzi-lo na memória coletiva." (AMÉRICO, 2016, p. 51).

Ao misturar ficção e realidade esses autores criaram atmosferas que influenciavam o leitor a mergulhar na história dos protagonistas de tal modo que podiam compartilhar com eles suas dúvidas e angústias. Para Rocha o autor deveria

Estar suficientemente perto da cidade para dela sorver o que há de mais expressivo na Modernidade que se consolida; estar suficientemente dela distanciado para não deixar sorver por seu ritmo alienante: esse é o desafio do olhar poético que se detém nos centros urbanos em meados do século XIX (ROCHA, 2012, p.112).

Um dos autores que trabalhou essa temática com enorme maestria foi Fiódor Dostoiévski, o qual utilizou a cidade de São Petersburgo, que para Toporov (2003), citado por Américo, tem um significado ímpar, uma vez que

A nenhuma cidade russa foram dirigidas tantas maldições, injúrias, desmascaramentos, insultos, recriminações, ofensas, lamentos, choros, desencantamentos, quanto a Petersburgo; o texto de São Petersburgo é excepcionalmente rico de representantes desse tratamento "negativo" para com a cidade, o que de maneira alguma exclui (e frequentemente supõe) fidelidade e amor (TOPOROV apud AMÉRICO, 2016, p. 11).

A história da cidade é peculiar, bem como o crime praticado por Raskólnikov e mais ainda a forma como o protagonista lida com o que fez.

São Petersburgo é uma cidade com uma história singular. Não surgiu pela vontade de seus moradores, nem pelo crescimento de um comércio local, tampouco por se localizar num [sic] área produtiva e de geografia agradável. Surgiu pela vontade de um homem, um tsar excêntrico, com mania de grandeza, não apenas porque media pouco mais de dois metros de altura. Era inquieto ao ponto de dominar 14 ofícios ao final da vida, variando da marcenaria à medicina. Pedro I, o Grande, queria equiparar a Rússia às grandes capitais europeias, especialmente Amsterdam, onde vivera sua juventude e aprendera, entre outras carreiras, o ofício de construtor naval.

$[\ldots]$

Deste modo, em 1703, a primeira construção foi erguida e fundou-se a cidade de Petrograd. Cidade que em pouco mais de três séculos mudou de nome quatro vezes, passou por três regimes diferentes de governo, viu o país ser invadido por forças estrangeiras duas vezes, foi cercada pelo exército nazista, passou por três enchentes avassaladoras que penetram profundamente no imaginário de seus moradores, além das centenas de milhares de mujiques que deixaram suas vidas sob o terreno pantanoso do estuário o Rio Nievá. [...] (FONSECA FILHO, 2010, p.14). 
Até o século XIX, a literatura russa seguia os padrões franceses, a partir de então "vai encontrar motivos internos, a razão e a inspiração pra sua retórica e poesia” (FONSECA FILHO, 2010, p.39)

São Petersburgo, ao apresentar os dois lados: sombrio e amável, demonstra não ser mais um lugar de abrigo, de refúgio, mas um lugar que poderia envolver seus habitantes em inúmeros sentimentos negativos e atitudes diversas. Senra fala sobre o papel das cidades nas atitudes das pessoas que nelas transitam,

a cidade passa a representar a própria civilização à medida que a vida urbana é vista como destino inexorável. A cidade deixa de ser um lugar de abrigo, proteção e refúgio, escapulindo à sua condição mineral e se torna um aparato comunicacional do entrecruzamento dos discursos do processo civilizatório. (SENRA, 2011, p.64)

A cidade mostra sua própria realidade por meio de seus habitantes e transeuntes e a literatura se apropria deste ponto para apresentar as personagens de suas narrativas, seu desenrolar e, muitas vezes, seu enigmático fim.

\section{Ficção e realidade em São Petersburgo}

A imagem de um crepúsculo no início de julho em São Petersburgo do século XIX foi a maneira encontrada por Dostoiévski para levar o leitor ao encontro do desespero de Rodion Románovitch Raskólnikov por comprovar sua teoria de que grandes homens da História teriam sido absolvidos de seus crimes.

Caminhamos com Raskólnikov pelas ruas da cidade russa, percebendo seu cotidiano envolvido pelo medo de encontrar com sua credora - um medo que lhe parecia insignificante perante o medo do que iria fazer - e seus questionamentos acerca da Humanidade, seus axiomas e seus paradoxos.

No decorrer da leitura o leitor é envolvido por uma atmosfera urbana na qual encontram-se misturadas ficção e realidade. Ricouer, citado por Brum, diz que "A experiência da leitura faz com que o sujeito entre na literatura, no espaço aberto entre a prática ficcional e o espaço vivido." (BRUM, 2009, p. 31).

Dostoiévski consegue fazer uma junção entre ficção e realidade em Crime e Castigo, por meio da cidade de São Petersburgo

Dostoiévski cria uma imagem concreta da cidade em um período igualmente concreto, com precisão topográfica e menções a locais reais e pontos turísticos da cidade. No caso, tal abordagem produz uma sensação de realidade aos fatos narrados. Por outro lado, o autor cria uma atmosfera estranha para uma imaginação consciente que segue o herói: o leitor perde o senso da realidade e deixa de visualizar seus limites. O motivo do calor e sufocamento na verdade são característicos igualmente para o estado tanto do herói, quanto da sociedade. (AMÉRICO, 2016, p. 56).

O narrador faz um retrato da cidade de São Petersburgo no verão, seu abafamento, seu odor, seu calor, que refletem os sentimentos do protagonista:

Na rua fazia um calor terrível e, para completar, o abafamento, o aperto, cal por toda parte, madeira, tijolo, poeira, e aquele peculiar mau cheiro de verão tão conhecido de cada petersburguense sem condição de alugar uma casa de campo - tudo aquilo afetou de modo súbito e desagradável os já abalados nervos do jovem. (DOSTOIÉVSKI, 2015, p.20).

Esse trecho encontra consonância com o texto de Brum:

A cidade faz convergir as temporalidades e os grupos humanos que nela habitam. Já a narrativa que se faz sobre a cidade dá sentido aos grupos humanos e suas experiências imediatas, desdobradas no cenário urbano. Esta narrativa, no entanto, para existir necessita que haja um urbano para narrar, isto é, um modo de vida, de morte, até que possa ser entendido como próprio do convívio citadino. (BRUM, 2009, p.29). 
Absorto em seus pensamentos, Raskólnikov é tragado pela cidade, ele parece ser tão comum, tão parecido com os outros, refletir tanto a cidade em que habita, que nem seria notado, conforme nos conta o narrador:

Estava tão malvestido que outra pessoa, ainda que habituada a tal situação teria vergonha de sair à rua de dia em semelhantes andrajos. É bem verdade que o quarteirão era um daqueles em que seria difícil ver alguém de terno. A proximidade da Siénnaia, o grande número de certas casas e a população predominante de artesãos e operários de oficinas, amontoada naquelas ruas centrais e travessas de Petersburgo, às vezes matizavam a paisagem geral com tais tipos que seria até estranho alguém admirar-se de encontrar uma figura esquisita. [...] (DOSTOIÉVSKI, 2015, p.20).

Nesse momento da narrativa, percebemos o retrato do Império Russo, apresentando uma pobreza generalizada, o aumento da criminalidade e a situação de embriaguez de diversos cidadãos, sendo ainda mais evidenciados no trecho em que Raskólnikov vai para uma taberna.

[...] Sei ainda mais que bebedeira não é uma virtude. Mas a miséria, meu caro senhor, a miséria é defeito. Na pobreza o senhor ainda preserva a nobreza dos sentimentos inatos, já na miséria ninguém o consegue, e nunca. Por estar na miséria um indivíduo não é nem expulso a pauladas, mas varrido do convívio humano a vassouradas para que a coisa seja mais ofensiva; o que é justo, porque na miséria eu sou o primeiro a estar pronto para ofender a mim mesmo. [...] (DOSTOIÉVSKI, 2015, p.30).

Continuando a leitura do trecho, Marmieládov, o interlocutor do protagonista, fala sobre Nievá, um rio de São Petersburgo, no qual havia lanchas de feno, lugar em que mendigos podiam pernoitar, com tal informação o leitor é situado na época em que se passa a narrativa, uma vez que sabemos que tal lugar era muito famoso na São Petersburgo da década de 1860. Um período em que o Império Russo começa a passar por grandes transformações: o início da Industrialização, as quais foram desenvolvidas pelo czar Alexandre II, que ascendeu ao trono em 1855. O czar percebeu o atraso em que o Império Russo estava submetido e resolveu tomar algumas medidas para alcançar avanços no Império, no entanto isso gerou miséria e uma grande crise na população.

Apesar de situar o leitor em um contexto real, o texto é ficcional e apresenta uma São Petersburgo criada por Dostoiévski, era só um reflexo da cidade real, conforme afirma Schnaiderman,

O real empírico mistura-se em Dostoiévski ao simbólico, a realidade aparentemente chã é, muitas vezes, paródia, estabilização de uma outra realidade, mas não apenas para iludir a censura, e sim num jogo de máscaras, de duplicação do mundo, de fragmentação da imagem numa oposição de "espelhos", enfim, na inserção da novela ou romance numa totalidade múltipla e variada ao infinito, dinâmica e fluida, em que o real é a máscara de outro real, em que nada é definitivo ou estratificado - conforme tem sido apontado por alguns dos estudiosos mais sérios da obra de Dostoiévski. (SCHNAIDERMAN, 1982, p.67).

Seguimos com o protagonista seus "exatos 730" passos ( $c f$. DOSTOIÉVSKI, 2015, p.22) que o separava de seu apartamento e seu destino, contados com precisão. Enquanto andamos com ele, é possível perceber que quanto mais ele caminha mais se sente angustiado. Cada passo parece fazê-lo como pertencente à cidade. Cada página narrada em Crime e castigo parece humanizar a cidade de São Petersburgo.

Essa afirmação encontra respaldo nos estudos de Américo,

Para Dostoiévski, a cidade vive uma vida humana: acorda, sorri, se enerva, sente frio, adoece; suas estátuas podem ganhar vida; as janelas dos edifícios agem como olhos que tudo observam, que perseguem os personagens em suas andanças.

São Petersburgo, para a criação artística de Dostoiévski, inicialmente é o local onde se desenrolam as ações dos personagens, já depois que os "defeitos" da sociedade, são apresentados, a cidade passa a influenciar os personagens. (AMÉRICO, 2016, p. 56) 
Raskólnikov ao andar pelas ruas da cidade russa revela uma imagem sombria, embriagada e confusa que reflete a confusão de seus sentimentos e pensamentos, desde o planejamento de seus atos até o seu arrependimento. Tais fatores são observados por Américo, segundo o autor,

Petersburgo é mostrada em sua obra por meio de sombras e miragens, em uma sensação embriagante onde nada pode ser visto com clareza: seja o futuro da própria cidade, criada por imposição do Imperador, contra a vontade da natureza, seja o destino dos personagens e da Rússia. Os protagonistas são acuados pelo estranho mundo fantasmagórico e trágico da cidade, seus pensamentos são atormentados. Por um lado, Petersburgo é um fundo social no qual se desenrolam os acontecimentos, por outro é um ator que testemunha atos bárbaros como o cometido por Raskólnikov e seu posterior arrependimento. (AMÉRICO, 2016, p.50)

A imagem da cidade que se apresenta entre coisas sombrias e claras, entre coisas desagradáveis e agradáveis, mostrando um contraste entre o claro e o sombrio, está refletida na imagem que Raskólnikov nos mostra de si mesmo e de outros personagens.

Uma imagem dicotômica que percebemos da cidade é a que antecede ao suicídio de Svidrigáilov, em que vemos nitidamente de um lado a escuridão da noite e de outro a claridade dos canhões, além da solidão e angústia dele diante da possibilidade da alegria de um parque de diversões.

Svidrigáilov acordou, levantou-se e caminhou para a janela. Pelo tato achou o ferrolho e a abriu. $\mathrm{O}$ vento arremeteu contra seu cubículo apertado e como uma geada gelada grudou-se em seu rosto e em todo o peito coberto apenas pela camisa. Debaixo da janela realmente devia haver alguma coisa como um parque e, parece, igualmente de diversões; era provável que ali também se cantasse de dia e se servisse de chá nas mesas. Agora voavam respingos das árvores para a janela, estava escuro como numa adega, de sorte que mal dava para distinguir umas certas manchas escuras que representam os objetos. Inclinado e apoiando os cotovelos no peitoril, olhava há uns cinco minutos para as trevas, sem despegar os olhos. No meio das trevas e da noite ouviu-se um disparo de canhão, seguido de outro. (DOSTOIÉVSKI, 2015, p.514-515).

Percebemos nesse trecho imagens antitéticas, claro e escuro, tristeza e alegria. Imagens fortes diante do que estaria por vir, continuando a narrativa, seguimos com ele pelo corredor vazio "Andou demoradamente pelo corredor longo e estreito sem encontrar ninguém, e já queria gritar alto quando subitamente distinguiu num canto escuro, entre um armário velho e a porta, algum objeto estranho, algo assim como uma coisa viva." (DOSTOIÉVSKI, 2015, p.515). Nesse trecho, permanecem as antíteses, temos o corredor vazio e o canto cheio de "uma coisa viva", que resulta na representação imagética do início da vida, representado pela criança, e pela morte, representada por Svidrigáilov, que cometerá suicídio.

O homem continua nos mostrando a cidade e seus passos, minuciosamente detalhados pelo narrador.

[...] Svidrigáilov tomou uma calçada de madeira suja, escorregadia, na direção do Pequeno Nievá. Teve a impressão de ter visto as águas do Pequeno Nievá subirem muito durante a noite, a ilha de Pedro, os caminhos molhados, a grama molhada, as árvores e os arbustos molhados e, por fim, aquele mesmo arbusto [...] (DOSTOIÉVSKI, 2015, p.518).

Continuando o texto, ele continua mostrando para onde está indo até encontrar seu fim.

Rejane Rocha (2012) ressalta que os escritores do século XIX passam a ter admiração pela cidade e suas mudanças, bem como por suas dicotomias e paradoxos:

O mito de atração e repulsa que está implícito no significado do vocábulo, emerge [dos] versos de Baudelaire, que olha para a cidade de finais do século XIX com o olhar crítico daquele que a sabe como repositório de todas as tensões de que a modernidade - e as novas relações de trabalho, de consumo e de produção que a caracterizam desde o seu surgimento - é agregadora e, ao mesmo tempo, a sabe, também, como fonte inesgotável de material poético (ROCHA, 2012, p. 107). 
A admiração dos autores pelas cidades ocorre, pois nesse século houve grande modificação das estruturas dos grandes centros, principalmente no que diz respeito à maneira como os cidadãos viam suas cidades. Os muros foram derrubados, a cidade já não era sinônimo de proteção, os espaços começam a passar por um processo de ruptura e com isso as pessoas que habitam tais espaços também começam a tornarem-se cada vez mais fragmentados.

$\mathrm{Na}$ São Petersburgo de Crime e Castigo conseguimos observar essas dicotomias, vemos por um lado uma cidade bem estruturada, que fora projetada para ser a capital do Império Russo, com todas as suas promessas de ser uma cidade promissora em que seus habitantes poderiam progredir com facilidade, e por outro uma cidade sombria, na qual seus habitantes encontram-se frustrados, embriagados e mergulhados em seus inúmeros problemas.

Conseguimos perceber essa dicotomia - Progresso/miséria - na fala de Marmieládov, o qual afirma ter ido para a capital com o objetivo de prosperar, mas sua realidade mostrou-se bastante diferente, tendo mesmo de levar sua única filha para obter a "carteira amarela" para ter comida para alimentar sua família, resultando em sua embriaguez e seu sentimento de impotência diante de Liebeziátnikov.

Dostoiévski, com essas personagens, consegue fazer emergir uma parte da população russa que vivia à margem, tanto da sociedade quanto da própria literatura. Dá voz a esses indivíduos, que por diversas vezes no romance têm oportunidade de contar suas histórias, dando notoriedade a situações reais que ocorriam no cotidiano do Império Russo. Levando a população a questionar, criticar ou simplesmente aceitar. Mas, acima de tudo, a ouvir. Não há escapatória, ao ler o romance temos de ouvir essas vozes esquecidas, sofridas, fragmentadas. Mostra também seus conflitos, desigualdades e contradições.

\section{Uma cidade e muitas vozes}

As cidades, principalmente as grandes, apresentam essa polifonia, seus habitantes vêm de vários lugares diferentes, com suas histórias, culturas, influências, idiomas, que se misturam em um único lugar, as ruas que compõem a cidade em que vivem. Isso gera inúmeras narrativas que se encontram nas encruzilhadas, nos becos, nas tabernas, nos mercados e nas casas da cidade. Toda grande cidade é assim, em São Petersburgo de Dostoiévski não poderia ser diferente. De acordo com Bakhtin

A multiplicidade de vozes e consciências independentes e imiscíveis e a autêntica polifonia de vozes plenivalentes constituem, de fato, a peculiaridade fundamental dos romances de Dostoiévski. Não é a multiplicidade de caracteres e destinos que, em um mundo objetivo uno, à luz da consciência uma do autor, se desenvolveu nos seus romances; é precisamente a multiplicidade de consciências equipolentes [consciências e vozes em pé de absoluta igualdade] e seus mundos que aqui se combinam numa unidade de acontecimento, mantendo a sua imiscibilidade (BAKHTIN, 2010, p. 5).

Em Crime e Castigo, observamos diversas vozes emanando de diferentes cantos da cidade russa, cada voz conta sua história e o seu ponto de vista em relação ao que viveram, sentiram e pensaram. Encontramos a pobreza e a embriaguez advindas das narrativas de Marmieládov bem como seu esgotamento.

\footnotetext{
- Caro senhor, caro senhor! - exclamou Marmieládov, recompondo-se. - Senhor meu, tudo isso pode servir de riso para o senhor e os demais, eu só faço incomodá-lo com a bobagem de todos esses detalhes miseráveis da minha vida familiar, só que para mim não é motivo de riso! Porque posso sentir tudo isso... E eu mesmo acalentei em meus sonhos fugazes a continuidade de todo aquele dia paradisíaco da minha vida e de toda aquela noitinha: ou seja, acalentei como iria dar jeito em tudo, vestir as crianças, dar a ela uma vida de conforto, tirar minha filha única da desonra e devolvê-la ao seio da família... [...] usando de um artifício como um ladrão no meio da noite, roubei de Catierina Ivánovna a chave do seu baú, retirei o que tinha sobrado dos vencimentos que lhe entregara, do total
} 
já não me lembro, e eis-me aqui, olhem para mim, todos! Faz cinco dias que saí de casa, lá estão à minha procura, o emprego já perdi, o uniforme deixei numa taberna da Ponte do Egito, em troca destas roupas... e tudo chegou ao fim! (DOSTOIÉVSKI, 2015, p.38).

Também ecoa a angústia e o amargor sentidos por Piotr Pietróvitch em relação a todos os boatos sobre Dúnia, sua noiva. Boatos que percorreram as ruas e as casas da cidade.

Ao lembrar há pouco a Dúnia, com amargor, que se atrevera a tomá-la como esposa apesar dos maus boatos que corriam a respeito dela, Piotr Pietróvitch fora sincero e sentia até uma profunda indignação contra tão "negra ingratidão". Entretanto, na ocasião em que pedira Dúnia em casamento, ele já estava absolutamente convencido do absurdo de todos aqueles mexericos, publicamente desmentidos pela própria Marfa Pietróvna e há muito esquecidos por toda a cidadezinha, que absolvera Dúnia calorosamente. (DOSTOIÉVSKI, 2015, p.317).

Nesse trecho, em especial, a voz de Piotr Pietróvitch é exposta por meio da fala do narrador e não de si mesmo, mas é possível observar cada pensamento e sentimento que emanam do personagem.

Está presente também no diálogo angustiante entre Sônia e Raskólnikov, que procura entender o que realmente havia acontecido e desejava uma explicação sobre suas meias palavras e seus discursos enigmáticos, com isso revela seu tormento e sofrimento diante de tudo o que sentia e, também, sua insegurança em relação a tudo que passara naquela cidade.

- Mas que verdade é essa! Oh, Deus!

- Acontece, Sônia, que matei apenas um piolho, inútil, nojento, nocivo.

- A pessoa é um piolho!?

- Ora, eu também sei que não é um piolho - respondeu ele, fitando-a de maneira estranha. - Aliás estou mentindo, Sônia - acrescentou -, faz tempo que ando mentindo... Não é nada disso; tu dizes coisas justas. As coisas são inteiramente, inteiramente, inteiramente outras!... Fazia tempo que eu não conversava com ninguém, Sônia... Agora estou com muita dor de cabeça. (DOSTOIÉVSKI, 2015, p.425).

Na afirmação de Svidrigáilov à Dúnia, sobre o crime de Raskólnikov e o desespero da moça, ao tentar negar o ocorrido:

- Ele roubou, eis todo o motivo. Pegou o dinheiro e os objetos. É verdade, por uma questão de foro íntimo ele não se aproveitou nem do dinheiro nem dos objetos, mas os levou para algum lugar e os meteu debaixo de uma pedra, onde continuam até agora. Mas isso foi porque ele não se atreveu a se aproveitar deles. (DOSTOIÉVSKI, 2015, p.498).

Continuando o diálogo, a voz de Dúnietchka que surge envolta em desespero, pois "tinha no coração um sofrimento incomensurável” (DOSTOIÉVSKI, 2015, p.497),

\footnotetext{
- Ora, por acaso é provável que ele fosse capaz de roubar, de saquear? Que pudesse sequer pensar nisso? - gritou Dúnia e deu um salto da cadeira. - O senhor não o conhece. Não o viu? Acaso ele pode ser ladrão?

Era como se ela implorasse a Svidrigáilov; havia perdido todo aquele seu pavor. (DOSTOIÉVSKI, 2015, p.498).
}

A cena de Mamieládov chegando carregado em casa por ter sido atropelado por uma carruagem é outro exemplo de mistura de vozes e até mesmo da invasão do espaço privado, como se um homem bêbado, que contava todas as suas histórias para todos em uma taberna deveria ser violado, por não existir mais respeito, uma vez que sua vida já estava degradada.

- Pólia! - gritou Catierina Ivánona. - Corre até Sônia, depressa. Se não a encontrares em casa, mesmo assim deixa o recado dizendo que o pai dela foi atropelado por causa de cavalos e que ela venha imediatamente para cá... assim que voltar. Vai logo, Pólia! Toma esse lenço, te agasalha! - Corre até não aguentar mais! - súbito gritou da cadeira o menino e, dito isto, tornou a mergulhar no silêncio anterior sentado reto ali na cadeira, de olhos esbugalhados, calcanhares expostos e meias cada uma para um lado. 
Enquanto isso o quarto ficara tão cheio que não havia onde caísse uma maçã. Os policiais tinham ido embora, menos um, que permanecera provisoriamente e procurava escorraçar o público que se amontoara desde a escada e fazê-lo voltar para a escada. Ao mesmo tempo, quase todos os inquilinos da senhora Lippevechsel haviam acordado e começaram a amontoar-se, a princípio junto à porta, mas depois se precipitaram em bando para dentro do quarto. Catierina Ivánovna teve um acesso de fúria.

- Deixem pelo menos morrer em paz! - gritou para toda a multidão. - Que espetáculo descobriram! E de cigarro na boca! Khe-khe-khe! Vão acabar entrando de chapéu na cabeça!... E tem um de chapéu... Fora! Respeitem ao menos um corpo morto! (DOSTOIÉVSKI, 2015, p.192).

Já não existe um limite entre o que é público e o que é privado, os personagens agem como se não se importassem com o que não lhes pertence, como se, na verdade, tudo fosse parte de algo que lhes é próprio a seu bel prazer. Não se importam com o homem moribundo, querem observar o "espetáculo", Gilles Deleuze fala sobre uma urgência que os personagens de Dostoiévski procuram, a qual chama de a fórmula de "O Idiota", pode-se perceber isso nesse trecho do atropelamento de Mamieládov, em que as pessoas estão preocupadas com algo além do moribundo

Em Dostoiévski, os personagens são perpetuamente vítimas da urgência e, ao mesmo tempo em que eles são vítimas dessas urgências, que são questões de vida ou morte, eles sabem que há uma questão ainda mais urgente, embora não saibam qual. E é isso que os paralisa. Tudo se passa como se, na maior urgência — "É um incêndio, é preciso que eu vá" —, eles se dissessem: "Não, existe algo ainda mais urgente. Não moverei um dedo até saber do que se trata". É "O Idiota" (romance de Dostoiévski filmado por Kurosawa). É a fórmula de "O Idiota": "Veja, há um problema mais profundo. Qual problema, não saberia dizer ao certo. Mas me deixe. Tudo pode arder... É preciso encontrar esse problema mais urgente" (DELEUZE, 1983, p. 187).

Apesar da fúria de Catierina, os vizinhos continuavam a tentar dar suas opiniões e suas vozes chegavam aos ouvidos da mulher como uma afronta que lhe rasgava a alma.

Lá de fora se ouviram vozes de pessoas que sugeriam hospital e que não convinha causar incômodos inúteis ao sossego do lugar.

$[\ldots]$

- Amália Ludwigovna! Eu lhe peço que se lembre do que está falando - começou em tom arrogante Catierina Ivánovna (ela sempre falava em tom arrogante com a senhoria para que esta "compreendesse o seu lugar" e nem agora podia abrir mão desse prazer) -, Amália Ludwigovna!

$[\ldots]$

Tudo isso ia sendo pronunciado com extrema rapidez, e quanto mais ela falava mais rápidas saíam as palavras, porém a tosse interrompeu de vez a sua eloquência. Nesse momento o doente voltou a si e deu um gemido, e Catierina Ivánovna correu para ele. Ele abriu os olhos e, ainda sem reconhecer onde estava em pé ao lado. Respirava pesado, fundo e espaçadamente; no canto da boca brotou sangue; na testa apareceu suor. Sem reconhecer Raskólnikov, ele olhou ao redor. Catierina Ivánovna olhava para ele com um olhar triste mas severo, e lágrimas lhe escorreram dos olhos. (DOSTOIÉVSKI, 2015, p.193-194).

Esse trecho mostra que as cidades há muito não são mais lugares de proteção, não há mais a defesa dos que dentro dela estão inseridos, como se todos fizessem parte de uma única família que se respeitaria e se protegeria, mesmo que por vezes brigasse por algum motivo. Os muros das cidades se desfizeram e com isso as pessoas que estavam dentro desses muros foram se compreendendo como rivais, como defensores apenas de si mesmo, no entanto encontravam-se frustrados por não conseguirem alcançar nem mesmo esse objetivo.

Além, é claro, do próprio discurso de Raskólnikov que demonstram suas teorias, suas convicções, seu sofrimento e seu arrependimento era um exemplo da polifonia que emanava das ruas da cidade e também de dentro de si mesmo.

É no meio da multidão, das inúmeras vozes que ecoavam ao seu redor, que Raskólnikov, desesperado por estar só, decide seguir os conselhos de Sônia e gritar a todos o crime que cometera, mas, em meio à confusão do centro da cidade, ao abaixar-se e beijar a terra, o máximo que conseguiu foi despertar 
nos transeuntes comentários distintos sobre o que realmente estava acontecendo e, por um instante, diante das inúmeras vozes que o rodeavam, pensou em desistir, em voltar para casa.

Ele entrou na Siénnaia. Achava desagradável, muito desagradável deparar-se com o povo, mas ele
caminhava precisamente para lá, para onde se via mais gente. Daria tudo no mundo para ficar só; mas
ele mesmo percebia que não iria ficar nenhum minuto só. [...] abriu caminho no meio da multidão,
olhou alguns minutos para o bêbado e súbito deu uma gargalhada breve e entrecortada. Um minuto
depois já o havia esquecido, nem o via, embora olhasse para ele. Por fim afastou-se, sem nem
sequer atinar onde estava; mas quando chegou ao centro da praça foi tomado subitamente de um
movimento, uma sensação logo e apossou dele, envolvendo-o por completo de corpo e pensamento.
[...] Tremeu todo ao se lembrar disso. E já estava tão oprimido pela desesperadora melancolia e pela
inquietação de todo esse tempo, mas especialmente das últimas horas, que acabou se precipitando
para a possibilidade dessa sensação inteira, nova, completa. Ela lhe chegou de súbito como uma
espécie de acesso: começou a lhe arder na alma como uma fagulha e de repente se apossou de tudo
como fogo. Tudo nele amoleceu, e as lágrimas jorraram. Do jeito que estava caiu no chão...
Ajoelhou-se no meio da praça, inclinou-se até o chão e beijou essa terra suja, com êxtase e felicidade.
Levantou-se e tornou a inclinar-se. (DOSTOIÉVSKI, 2015, p.533-534).
No entanto, seguiu em frente e confessou seu crime: “- Fui eu que matei com um machado a velha
viúva do funcionário e sua irmã Lisavieta e a roubei.” (DOSTOIÉVSKI, 2015, p.539, grifos do
autor).

Tal polifonia representa o movimento diário das cidades, o barulho comum provocado pelo andar das pessoas com seus sapatos barulhentos, as conversas de amigos, amantes, cônjuges, famílias, sócios, que caminham juntas, conversando sobre uma conta que precisam pagar, um negócio que estão para fechar ou um assunto que ficou inacabado. Todas as vozes juntas, mas excepcionalmente distintas, como um emaranhado de ruas que se cruzam e juntas, cada uma com suas particularidades, formam a cidade na qual se encontram.

Como afirma Bakhtin, Dostoiévski não apresenta apenas diversas vozes, que falam de maneira individual ou coletiva, mas apresenta a polifonia em seus romances por meio da consciência dos personagens. A voz de outrem se manifesta na fala do narrador, que expressa os sentimentos e os desejos mais íntimos dos personagens, bem como o reconhecimento de suas atitudes e suas possíveis consequências, resultando na consciência de seus atos e do que ele poderia vir a ser.

Os personagens interagem, dialogam e expressam-se de diferentes maneiras, suas vozes são ouvidas por toda a cidade, em locais públicos como é o caso da taberna ou locais privados como é o caso do quarto de Sônia ou o apartamento de Svidrigáilov.

\section{Considerações finais}

A cidade é utilizada por diversos escritores do século XIX como forma de apresentar as modificações sofridas pelas sociedades, pela escrita e pela forma de narrar com o passar do tempo.

Tal estratégia narrativa apresenta uma diversidade de opções, pois se mostra sempre em movimento, sendo modificada constantemente e habitada por inúmeros seres que vêm e vão o tempo todo, ressaltando o burburinho provocado pelas inúmeras vozes que perpassam de um lado para o outro, que se escondem nos lugares mais ermos e no íntimo das casas.

O presente artigo procurou mostrar a importância de uma cidade específica na construção da narrativa de Dostoiévski, São Petersburgo. Essa cidade marcou inúmeros romances do autor russo e foi palco de diversas histórias com inúmeros personagens. Neste trabalho, utilizou-se o romance Crime e Castigo, que situa a São Petersburgo da década de 1860.

Procurou-se revelar as condições por meio das quais a cidade foi criada e toda a repercussão que isso gerou em seus moradores, bem como os problemas advindos da crise durante o governo do czar Alexandre II, que deu início à Industrialização russa, acarretando em aumento do desemprego, da 
pobreza, levando os petersburguenses a procurarem alternativas precárias, ou até mesmo ilícitas, para tentar sobreviver nesse cenário que não lhes mostrava um futuro próspero.

A cidade começou a apresentar um crescimento às custas dos menos favorecidos, Alexandre II não media esforços para conseguir fazer com que a capital do Império Russo fosse a capital mais bela e moderna da Europa. A vontade de imprimir significações e culturas próprias do continente vizinho fez com que São Petersburgo não fosse reconhecida pelos russos como lugar de pertencimento. Na busca por melhorar suas condições, muitos iam para países europeus para obter melhor educação, quando voltavam para seu país de origem sentiam-se deslocados, com sentimento de não pertencimento, afinal não eram europeus e não se sentiam bem com o que viam no Império Russo.

Essa falta de perspectiva é vista em Crime e castigo, os personagens se encontram no meio dos conflitos que o próprio Império Russo vivia. Não sabendo se deveriam continuar seguindo seus ideais, que em alguns momentos nem sabem quais são, ou se deveriam abrir mão de certos pensamentos buscando sobreviver a condição de miséria na qual se encontravam.

Todo o caos dessa cidade, apresentado de forma brilhante por Dostoiévski, reflete na atitude e na degradação dos personagens, que são reflexos da cidade em que habitam.

O autor consegue mostrar os diversos problemas do desenvolvimento tardio da Rússia, a maneira como a industrialização começou a aparecer, mediante a vontade do czar, a qualquer preço, levando uma nação a sérias dificuldades e até mesmo a custas de várias vidas que foram degradadas durante o processo. Com suas narrativas sobre a cidade de São Petersburgo, a forma como constrói a história fundamentada nela, consegue criticar seu processo de desenvolvimento acelerado, sem nenhum planejamento e mostrar o reflexo disso na população russa, tão bem representada na imagem de seus personagens.

O autor russo mostra diversas vozes, que em algumas situações aparecem de forma distinta, separadas umas das outras e em outras situações essas vozes são misturadas, enlouquecidas e perturbadoras para o protagonista, que apenas gostaria de ficar sozinho com suas próprias vozes interiores, que tanto o atormentam.

Outro ponto importante são os encontros e desencontros que a cidade proporciona, além da luz em detrimento das sombras, os paradoxos e dicotomias presentes nos centros urbanos. A necessidade de evolução de um lado e as consequências dessa evolução para a população do lugar, a miséria que ela gera. A defesa pelos ideais bem como a necessidade de ir contra eles pela sobrevivência e a necessidade de afirmação dos propósitos de todas as atitudes tomadas, buscando justificar seus atos por meio de teorias.

A cidade em Crime e Castigo parece espremer os personagens, acuando-os em seus apartamentos e levando-os a um imenso sofrimento, que parece aumentar à medida que a narrativa evolui.

Mostra-se assim que as personagens são apenas fragmentos que compõem a narrativa ao mesmo tempo em que são seres fragmentados pela própria modificação da cidade do século XIX. Revelando, por sua vez um paradoxo, que consiste na busca pela unicidade do ambiente composto por seres que não se sentem unidos, não sabem como se unir e se atacam e se desconstroem cada vez mais.

Dessa forma, o presente artigo procurou mostrar a importância da cidade para a literatura universal, principalmente na obra de Dostoiévski, em especial, no romance Crime e Castigo. Abrindo espaço para a reflexão sobre a temática, tanto no tange a obra do autor russo quanto na literatura de maneira geral.

Muitos estudiosos já abordaram a temática, mostrando o papel fundamental da cidade em diversas obras, entretanto cada nova leitura corrobora para tal afirmação, sendo um assunto importante e que apresenta inúmeras possibilidades de leitura e releitura, contribuindo para o estudo da Teoria da Literatura como um todo. 


\section{Referências}

AMÉRICO, Edelcio. Petersburgo: personagem atuante em Crime e Castigo. In: RUS - Revista de Literatura e Cultura Russa. São Paulo. v. 7, n. 7, jan/jun 2016, p. 49-60 Disponível em: <https:// www.revistas.usp.br/rus/article/download/114018/111871> Acesso em: 24 de fev. de 2018.

BAKHTIN, M. Problemas da poética de Dostoiévski. Tradução de Paulo Bezerra. Rio de Janeiro: Forense Universitária, 2010.

BRUM, Rosemary Fritsch. Uma cidade que se conta: Imigrantes italianos e narrativas no espaço social da cidade de Porto Alegre nos anos 20-30. São Luís: Edufma, 2009.

DELEUZE, G. Cinema 1: a imagem-movimento. Tradução de Stella Senra. Rio de Janeiro: Editora Brasiliense, 1983.

DOSTOIÉVSKI, Fiódor. Crime e Castigo. Tradução de Paulo Bezerra. São Paulo: Editora 34, 2015.

FONSECA FILHO, Odomiro Barreiro. A cidade de São Petersburgo na obra do jovem Dostoiévski. Dissertação (Mestrado em Teoria da Literatura) - Universidade Federal de Pernambuco, Recife, 2010.

OLIVEIRA, Suzana Vieltz. Valores da vida e qualidade urbana: o imaginário urbano e a construção das cidades. PNUD - Relatório de desenvolvimento humano, Recife, 2009, p. 1-12.

ROCHA, Rejane. As foras do real: a representação da cidade em "Eles eram muitos cavalos". Estudos de Literatura Brasileira Contemprânea, n.39, jan/jun 2012, p.107-127.

SCHNAIDERMAN, Boris. Dostoiévski: Prosa Poesia. São Paulo, Perspectiva, 1982. (Debates)

SENRA, Márcia. A cidade moderna: história, memória e literatura - Paris, Belo Horizonte. Revista

Univap. São José dos Campos - SP, v. 17, n.29, ago. 2011. p.62-79 
